\title{
MODERNISMO: A COMPARATIVE STUDY
}

\author{
HENRYK ZIOMEK \\ University of Georgia
}

Modernismo, a form of cultural and especially literary upheaval, is a complex phenomenon that faded away by now in the Hispanic world. Today Modernismo can be viewed as a universal revolution as well as a stage in literary history.

Usually two opposing forces can be discerned in a movement: rise and fall. In the first case, we deal with the avant-garde of the particular cultural literary movement. When discussing the fall of a movement, one can unveil the similarities among creative poets, who once were partakers of the vanguard, but later strode their own ways. The poets' common share, thus, in shaping the passing period of literary activities is revealed. Hence, by Modernismo, in this study should be understood the early preparatory period of young poets such as Nájera, Martí, Casal, Silva, and Darío. It is difficult to determine precisely either the movement's origin or its apex with dates. In general, the year, 1882, when Martí(1) and Nájera wrote their firsi modernista poetry can be set as the terminus a quo and the year, 1896(2), in which Dario's Prosas profanas was published, as the ter. minus ad quem. Dario's book synthesized Romantic sentimental phe nomena with the finely sculptured Parnassian verse and with symbolic nuances and word-music; in this way, Dario's work established the modernista renovation in the Hispanic world and thus it is considered to be the height of the rise of Modernismo.

1. In that year Marti wrote his Ismaelillo and Versos libres.

2. By 1896 Martí, Nájera, Casal, and Silva had died, thus, establishing a new modernista renovation and passing its responsibility to Dario and others. 
The primary aim of this study is to identify Modernismo by de fining its traits in comparison with its immediale antecedents. To observe chronological unity, I will deal with the first stage or rise of Modernismo from the point of view of its comparative structure.

Many dualistic factors contributed to, and shaped the character of Modernismo. During the years of the psychological maturing of its poets, Spanish Americans still lived in a funcamentally medieval society, albeit one whose forms were beginning to change. In the literary world, Romantic and naturalistic influences were being weakened by the changes in the worlds of science, the arts, and culture. Since the Spanish-American Romantics and naturalists limited themselves to the painting of picturesque exteriority rather than to a deeper interpretation of the character of their race, they did not truly grasp the real spirit of the New World. The two movements, however, stimulated a curiosity for life, ideas, and European literature. Modern occidental culture, through cosmopolitan Paris and the contributions of European immigrants, imposed something of its values and scope on South America, bringing spiritual meanings that reestablished hatred toward traditionalism and provoked anxiety for progress(3). Spanish-American poets, lacking geruine native themes, nourished themselves on foreign topics which seemed to them more perfect and consistent.

Lastly, the negative conditions of the struggling lives of young poets created in them an attitude of pessimism; consequently, in Mo. dernismo feelings of mystery and the everlasting sufferings of a superior individual are present. The poets, with their negative views brought about a reaction against realism and naturalism in literature, against Comte's positivism in philosophy, and against the conformity of the social aspect of bourgeois life. With the bankruptcy of naturalism the fall of the sciences was evidenced, and the war against Philistinism was waged. The modernistas, with their Romantic heritage, defied industry, materialism, experimenta! sciences, the bourgeoisie, and capitalism. They rejected reality and the present, preferring to live in an escapist's world.

The modernista poets drew upon almost all of the artistic resources in the Western World. From the creative point of view, their work was the result of a skillful assimilation of artistic and literary trends and schools. Theirs was an art grafted upon art-not a copy of it--since the poets created their art in their own ways.

Cosmopolitanism was their primary source of inspiration for the

3. Francisco Contreras, Rubén Dario (Santiago, Chile: Ediciones Ercilla, 1937), p. 36. 
modernista poets, artists, and thinkers searched for refined spirits everywhere. Philosophically, during the 19th century, they were interested in Bergson's intuitionism, in Schopenhauer's voluntary pessimism, in Nietzsche's idealized morality of superiority, in Kierkegaard's anguish, and in Tolstoy's neo-Christianism. In music their love was for Wagner, Chopin, Schubert, Rameau, and Lully, In literature the modernistas worshipped Romanticism, the Pre-Raphaelites, Parnassianism, and symbolism. In drama their idols were Ibsen, Maeterlinck, and Hauptmann, and in poetry they were Verlaine, Oscar Wilde, D'Annunzio, Whitman, Poe, Gauthier, Beaudelaire, and others. They were even drawn toward Emerson and Poe's transcendentalism, which previously had influenced much of Europe.

As these influences suggest, Modernismo was eclectic in character. Many qualities inherited from other schools and movements synthesized the shifting combination of artistic elements that is called Modernismo. There are in it certain sentiments and ideas that can be generally classified under the name "Romantic" such attitudes as love, despair, enthusiasm, messianism, melancholy, mystery, and anguish. These attitudes are present in all the intellectual or effective modernista manifestation. Like the modernistas the Romantics did not insist on the originality of their emotions. Even though they separated themselves from the rest of the world, they expressed human emotions through their themes. They were concerned with man in relation to God, nature, misery, and eternity. They pondered problems of destiny.

Both Romanticism and Modernismo were in opposition to their previous academic traditions. Modernista and Romantic poets both sought to obliterate old, worn-out literary forms and to produce a universal culture through a more sensitive, richer expression. Both movements rebelled against the authority of any single author, as can be summed up by Pascal's thought, "Le moi est hayssable".(4) They demanded complete liberty in art, along with the recognition of an individual's right to express his own ideas and passions in any form; nevertheless, modernistas rejected the Romantic's artificial eloquence and showiness in language and literary style. In spite of this difference, however, the aim of both movements was to recreate language - the literary instrument - and verse - the poetic instrument. In order to make the language capable of expressing their sentiments and sensations, writers of both movements found it necessry to reconstruct vocabulary, form, style, and versification. $\mathrm{Na}$ -

4. Blaise Pascal, Pensées, ed. H. F. Stewart (London: Routledge and Kegan, 1950), article 146, p. 78. 
turally Modernista poets drew inspiration from the example of the Romantics. Dario himself, in "Canción de los Pinos", acknowledged, "Románticos somos. Quién que es, no es romántico?" Modernismo, owing an immediate and initial impulse to Romanticism, accepted from the older movement its idealistic, individualistic aspects and protesting traits; but Modernismo rejected as substandard the Romantic's rethorical art, which used words to influence or persuade others.

Modernismo inherited many qualities from Parnassianism, the reactionary movement that rebelled against Romanticism, preferring art with no autobiographical implications - impassive, marble-like and purged of emotion(5). This is of course an old idea borrowed from the classicists. The second important tenet that Modernismo adopted from Parnassianism was the doctrine of "art for art's sake". Form was most important to the Parnassians, who considered eacn poem almost like a jewel to be polished and coaxed into perfection by endless, patient work. Their poetry was descriptive, pictorial, plastic, and sculptural. Parnassian poets were obsessed with oriental beauty of form, color, and design; they were delighted with oriental portraits of animals and exotic lands. Their conception of achieving art was like that of the naturalists. In their preoccupation with concrete reality, they had little interest in God; their art was rather pagan and pantheistic. At one time or another, the modernistas followed to some extent many of the Parnassian tenets.

Like many movements which seem quasi-relıgious, Parnassianism had its creed - one whose attention was given to form and the perfection of technique. In a few poems like "Elena" and "La Maja" by Casal, the modernistas followed the pure Parnassian literary creed; but in the majority of their poems they strayed somewhat from the theory. Most Spanish-American poets objected on this point, since the Parnassian was expected to remain divorced from his subject matter, thus frequently producing technically flawless poems without feeling, which therefore failed to move the reader profoundly. Even though the Parnassians exercised a great influence on form in modernista poetry, its impersonality could not please the Spanish-American character, whose temperament was much too individualistic.

In evaluating artistic modernista expressions, one may not only find comparative evidences and identify general tendencies, but also study negative factors that influenced the movement. The ever-present undercurrent of Parnassianism acted like a vexatious agent within Modernismo. Parnassianism, by accentuating the importance of

5. Francis Vincent, Les Parnassiens (Paris: Gabriel Beauchesne et Ses Fils, 1933), p. 28. 
the artist's métier, expressed itself in precision, intellectualism, and closed lyricism; whereas, Modernismo leaned toward indefiniteness, composure, and direct lyricism. The modernistas, furthermore, felt that poetry should have a message or mission in the style of Victor Hugo's doctrine(6); and this was contradictory to the Parnassian belief. The modernistas were not savants or intellectuals, although they were cultured, educated people; their poetry can be more easily understood than Parnassian poetry. Finally, in contrast to the emotionless Parnassian poetry, modernistas' writings usually show certain melancholy, which some critics aftribute to the youth of the countries and the writers themselves.

The first poems written by the modernistas reflect to a certain extent Parnassian flavor because they contain a certain emphasis on objectivity and perfection of metrical form; still these poems already hold a strange hint of Baudelaire's impressionims. It can already be seen that in these early poems, the modernistas were adopting new symbolistic attitudes, notably sonority, stressing for the ear rather than the eye. At the time when symbolism came into vogue in the literary world, Parnassianism was dying out; stili it had enough in fluence to cause vexation among poets.

The modernistas felt more affinity toward symbolism, the movement that revolted against positivism and the earth-bound naturalistic school and that exalted metaphysical and mysterious values. Proclaiming Verlaine's poetic manifesto, "music before all else", the symbolists cultivated such diverse qualities as inner music, new poetic cadences, vagueness, harmony between content and form, reem phasis of sadness leading into despair, and anguish in the form of "mal du siècle". Nevertheless, they considered the symbolists' exaggerated subtilties and display of emotion to be defects, and they never accepted these extremes.

Symbolism had an undercurrent of French decadentism, whose characteristics were flight and treason. The decadents openly admired Roman decadence; they reacted and protested against the bureaucratic life brought about by the empire of Napoleon the Third. The sentimental overtones of decadentism were caused by emptiness, pessimism, and lassitude; decadent sentimental ethical structure can be easily discerned in the modernistas' spirituality. The modernistas' suffering first consisted in their wish for revel and enjoyment in the form of desperate hedonism; then it changed into the desire for no-

6. According to Hugo, the poet had to be "l'écho sonore de tout ce qui l'entoure." This was not all of the poet's mission, however, because Hugo ciso felt that the poet was obliged to lead ordinary men and guide them in thought and actions. 
thingness in the form of nirvana or death Their way of joining death with hedonism led them out of free choice to destroy any bond with reality. This philosophy of life is evident not only in their works but also even in their lives.

The main artistic endeavor of Modernismo was to generate a tendency toward indefiniteness - a conscious effacing of the limits of vision and feeling. Symbolistic vagueness together with Parnassian composure were the torches that lighted modernista lyricism, but decadentism always remained an undercurrent. A modernista lyricist, for instance, did not create a landscape in order to use it in its real form but to destroy its proportions and remove its concreteness for the purpose of broadening, enlarging, and magnifying the empti ness. In their poems, the modernistas presented flowers and other types of vegetation as having certain symptoms of sensationalism. By means of the French decadents and the symbolists, the Modernis. tas took a step farther than the Romantics did.

Spanish-American writers, having always been entangled with Spain because of a common language, were interested more in Bécquer and Rosalía de Castro than in Campoamor, Núñez da Arce, Ma. nuel del Palacio, or Bartrina (who led poetry toward a plebeianism that is characterized by vulgarity, shallowness, and triviality). it could be said that Bécquer and Rosalia de Castrc, on account of the vagueness, interior musicality, and sentimentality that fill their works, were like the sunset for Romanticism and at the same time the dawn for Modernismo. Young Spanish-American poets with a more vivid sensitivity than that of the progenitors such as the Mexican, Manuel Gutiérrez Nájera (1859-1895), turned their attention toward Paris the "Mecca" for the trends in arts - and reacted against bombastic rhetoricism and false costumbrista Romanticism(7).

As a poet and the founder of the Revista Azul (1894), Nájera paved the way for Modernismo. His works represent a transitional stage between late Romanticism and Modernismo. Essentially, of course, he was a romantic. He did not experiment with metrics or rhyme schemes, but brought melody into Spanish prose (e.g. Cuentos de color de humo) and verse (e. g. "La serenata de Schubert" and "Después del Vals"). His prose, in the form of lyrical whims with humorous traits, has profound melancholy. From Musset's "Nuits" and particularly André Chenier's sixth "Elegy" (one line of which reads, "Je meurs, Avant le soir j'ai fini ma journée), Nájera derived a type of Romantic anguish and sentimental despair. He excelled particularly in writing elegies: "¡Mi pobre lira/ sólo exhala sollozos/

7. Contreras, p. 36. 
sólo suspira!" Nájera reached a culmination in his Romantic nd, to a certain degree, decadent feelings when expressing wishes for death such as in "Para entonces."

Quiero morir cuando decline el día

en alta mar y con la cara al cielo;

donde parezca sueño la agonía...

Profiting greatly from his reading of the Parnassians and the early symbolists, Nájera found color in Gautier and the praise of music in Verlaine(8). In his "De Blanco" (1888), Nájera owed a debt to Gautier's "Symphonie en Blanc Majeur." A correspondence between sound and color exists in the poems. Furthermore, there are astonishing similarities in subject matter and approach in his "Pax Animae" and Leconte de Lisle's "Le Vent Froid de la Nuit." When reading Najera's line, "reclinarse fatigado en el hombro de nieve de olvidado," $(9)$ one is reminded of the image "I'herbe de l'oubli" found in "Le Vent Froid." Both poems have a characteristic cold calmness. Leconte's admonition to endure grief and pain, his belief that life is vanity, his use of color images, and his dislike for people and love for nature had much influence on Nájera. Wherever Nájera deviated from Leconte's Parnassian thinking, it was in the hope that there is a God to whom he could turn; for Nájera hoped to believe, even though he found it impossibly difficult (e.g. from "Después", "¿En dónde estás, oh Cristo?/ ...ya me ahogo!/ ¡Resúcita, Díos mío!").

Nájera's Parnassian and symbolistic type of Gallicism can be discerned in a combination of sensual and musical versification in which music becomes a language suitable to express all kinds of passion. An example of this is in his "La Duquesa Job":

rizos tan rubios como el coñac;

esprit rociado de Veuve Cliquot.

como los ojos de Luise Théo!

A symbol as an image appears neatly expressed in his poem, "Luz y Sombra", one line of which is, "Mi alma negra sombra, la tuya blanca luz." Nájera's poetry, especially when if was signed under the pen name of "El Duque", synthesizes aristocratic elegance, selfworship, humor, and a longing to die prematurely, which are all modernista elements.

8. Alfred Coester, An Anthology of the Modernista Movement in Spanish-America (Boston: Ginn and Company, 1924), p. 232.

9. Manuel G. Nájera, "Pax Animae", An Anthology of Spanish-American Liferature, ed. E. Herman Hespelt (New York: F. S. Crofts and Co., 1946), p. 435. 
A renewing action in prose was displayed by José Martí (185395) in his patriotic type of manifestos, which are filled with modernistic sensations. In his prose neatness, flexibility, and color can be observed; in his children's stories, such as "Muñeca negra", certain nuances and modernista stylistic proprieties are achieved. In poetry, Martí turned toward new images that were both spiritual and exotic, giving a flame rich in sensibility and passion. This can be exemplified in "Maria" written before 1881 in Versos Varios: "es un jazmín de Arabia comprimida/ en voz de cielo y en contorno de ave."

In the verses of Ismaelillo (1882), Martí embellished his poetry with picturesque images, details, and archaisms, which gave a fresh touch to poetic expression in his day. Marti showed himself to be a dreaming patriotic idealist in his heroic poem, "Claustros de mármol" (Versos sencillos, 1891, XLV). Intimate symbols are visible in this poem:

\section{... resuena}

La piedra: buscan el cinto

Las manos blancas: jdel soclo

Saltan los hombres de mármol!

It is evident in such lines as these that the poet's interest lay more in the Castillian baroque than in French poetry.

In Versos sencillos the poet moved dynamically against static prosaism and rhetoricism, and he spread North American esthetic cultural elements. Furthermore, Martí showed his ccnsciousness for the métier of a writer. In his concept, the poem is within the man and in nature; this is clearly stated in the first verse of his Versos sencillos:

Yo soy un hombre sincero

- .

Arte soy entre las artes,

En los montes, monte soy.

Yo sé de nombres extraños

The works of Julian del Casal show the poet's affinity to the Parnassians, the decadents, and the Pre-Raphaelites. As a most lonely person, Casal liked to collect art treasures and, like Leconte de Lisle, studied every facet of them. Being a sickly, unhappy youth, whom Blanco-Fombona called, "romántico por temperamento y parnasiano por anhelo de perfección formal,"(10) Casal was a poet who revealed his morbid, hypersensitive temperameni in his works.

10. Rufino Blanco-Fombona, El Modernismo (Madrid: Editorial Mundo Latino, 1929), p. 87. 
Fond of Parnassian art and interested in ancient history and exotic places, the Cuban poet was attracted to the oriental fragrance of Gautier, Loti, and Goncourt. In Casal's second book, Nieve (1892), both treatment and subject matter - especially in "La muerte de Moi sés" and "El camino de Damasco" are reminiscent of Leconte de Lisle's style. The Cuban poet revealed his own natural gift for understanding pure, perfect beauty in impersonal art. In his Parisian, adjectival type of sonnets, "Elena", "La Maja", anci "Salomé", he was inspired by the cult that worships beauty for itself alone in the manner that J. M. de Hérédia did. The sonnets are also reminisceni of the lovely "Vénus de Milo" from Leconte's La Fhalange.

Casal's decadentism is in the style of that which is seen in Baudelaire's "Fleurs du mal," but it is slanted toward the transcendental pessimism of the Pre-Raphaelites. For example, in his poems "La agonía de Petronio," "Nihilismo," and Flores, "refined sensation-ima ges are present. His sad poetry lacks erotic elements and descriptions of native landscape. Inspired by nihilism, he lived and wrote with an obsession for dying.

In the poems, "La canción de la morfina," "Horridum somnium" and "Cuerpo y alma," Casal seemed to be dazzled occasionally by Baudelaire's impressionistic type of image (e.g. "visión sangrienta de la neurosis") and with the symbolistic art of synesthesia (e.g. "percibe el cuerpo dormido/por un mágico sopor,/sonidos en el color,/colores en el sonido.").

A notable exponent of symbolism and a staunch decadent among the modernistas was José Asunción Silva (1865-96), who found delight in such poets as Verlaine, Mallarmé, D'Annunzio, Heine, Poe, and Baudelaire. Being a modernista explorer in the mystery of existence and in the vagueness of feelings, Silva cultivated an impressionistic type of synesthesia. In his lyric poems he was an innovator ot certain musical tones by using metaphors in which the elements of color and feeling are fused and by employing ideological as well as rhythmic rhyme.

Silva's third "Nocturno," which begins, "Una noche," is completely reminiscent of Chopin's "Prelude," opus 28, no. 2 . In the poem the constant repetition of the briefest intelligible fragment of a theme - which is the vowel "a" - in a rhythmic pattern is exactly like Chopin's treatment of the constant repetition of the light motive which is actually a-flat - around which the music is artfully woven. This is not just a Romantic procedure; it is really a symbolistic technique, which to a certain degree can be compared to the style Verlaine used in "Chanson d'automne." This symbolism produces a sensation 
in which vagueness is achieved and certain shades in nuances and rhythm achieve the art of synesthesia. The sound of the rhythm is transformed into the color of the night, the fragrance of the evening air, and even the movement of the wind and light. Being almost musical compositions with harmony between color and sound, feelings and imagination, and thought and erotic exaltation, Silva's "Nocturnos" awoke a new poetic consciousness for the modernistas.

When Dario appeared on the poetic stage, the restless spirit of the age had already been awakened. Nájera and Marti, by paving the way for Modernismo, had launched the creative cycle; and Casal and Silva had achieved the modernista poetic renovation.

Dario assimilated the best from every influerice and transformed it into his own, having been endowed with the natural gifts of lyricism and art. He possessed a rare genius that enabled him to search for influences without imitating, and to condense all of the modernista achievements made by Nájera, Martí, Casa!, and Silva. While systematically exploring and absorbing the influences from the Spanish Middle Age, the classics, Eighteenth Century France, and modern contemporary life, he made the foundation for the modernista renovation, which culminated in him.

Darío's harmoniously creative poetry placed him as the focus of the greatest brilliance among his contemporary Spanish-American writers. Dario became the indisputable chief of the Modernista Movement and Latin America's greatest literary voice(11). Without Darío, Modernismo might never have become a world force. It was his amazing genius that carried the new expression to its greatest heights(12). This amazing Nicaraguan, thus, was first among contemporary poets to sucessfully raise Modernismo as an American ex pression in world literature.

11. E. Herman Hespelt, ed. An Anthology of Spanish-American titerature (New York: Appleton Century Crofts Inc., 1946), p. 481.

12. Arfuro Torres Rioseco. The Epic of Latin-American Literature (Nsw York: Oxford University Press, 1942), p. 86. 
Elements of Other Schools in Modernismo

Romanticism

\section{Adopied from}

1. Sense of individuality

2. Refusal to accept authority in search for expression

3. Originality in every act

4. Distraction as an escape

5. Idealism

6. Messianism

7. Anguish and despair

8. Melancholy and sadness

9. Solitude and bitterness

10. Mortality as expressed in the concept of "passing beyond"

11. Protest

1. Cultivation of form

2. Consciousness of "métier"

3. Objectivity

4. La mesure (selected word in selected place)

5. Rhyme

6. Virtuosity

7. Sense of aristocratic intellectuality, i.e. elegance, egolatría (self-worship)

8. Exotism

9. Pessimism

\section{Parnassianism}

1. Rhetoricism

2. Devoticn to the past

3. Attachment to nature

4. Spontaneity

Rejected from
1. The element of coldness
2. Atheism to the degree that the Par nassians were

\section{Symbolism}

1. Vagueness for musical lightness

2. Cultivation of inner music

3. New poetic cadences

4. Harmony between content and form

5. Suggestions in forms of sensations

6. Synesthesia

7. Re-emphasis or sadness, despair (mal du siècle)

8. Hedonism

9. Lack of ideas substifuted with colorful and sonorous phrases

10. Obscurity so that each reader finds different subjective interpretation

11. Mystery

12. Virile love for a perfect woman expressed in exotic passion (oriental concept of love)
1. Exaggerated subtility

2. Exaggerated emotions 